\title{
A trajetória de Ilda do Prado Lameu: dinamismo popular e cidadania em uma periferia do Rio de Janeiro*
}

\author{
Linderval Augusto Monteiro**
}

É antiga a luta pelo alcance de cidadania no Brasil, e esta tem sido estudada muitas vezes através do acompanhamento das manifestações políticas levadas adiante por grupos sociais organizados - alguns muito visíveis, como o conjunto dos trabalhadores brasileiros, outros não tão visíveis, porém muito engajados, como os homossexuais. Quase sempre organizações não governamentais representam esses grupos em nossa época, que José Murilo de Carvalho classifica como aquela em que ocorre a "expansão final" dos direitos políticos e civis (Cf. Carvalho, 2005. p. 199 ss.).

Mas e se nos depararmos com um grupo aparentemente desorganizado, quase absolutamente não incluído socialmente e ignorante de seus direitos e deveres e por isso facilmente classificado como distante de qualquer consciência cidadã?

O problema não existiria se esse grupo não se esforçasse para mudar o mundo ao seu redor, conformando-se com as adversidades componentes de seu cotidiano. Ocorre que, diferentemente disso, o grupo do qual me ocupo foi o responsável pela alteração de várias situações desvantajosas ante as quais o Estado, embora solicitado, não se mostrou

* Este texto inspira-se em um dos capítulos de minha tese Retratos em movimento: vida política, dinamismo popular e cidadania na Baixada Fluminense, defendida em abril de 2007 sob a orientação da Profa. Dra. Marieta de Moraes Ferreira a quem sou grato por incontáveis conselhos nem sempre seguidos e sob o financiamento da CAPES.

** Doutor em História Social. Professor do Centro Universitário Estadual da Zona Oeste (RJ). 
presente de forma efetiva, interferindo esporadicamente e em momentos emergenciais somente.

$\mathrm{Na}$ verdade é quase impossível até mesmo descobrir os rostos das componentes desse grupo que, por combater primeiramente agressores de mulheres e crianças, escondia-se atrás de lenços cuidadosamente colocados sobre o rosto. Talvez por isso o relato a seguir centralize-se na figura ímpar responsável pelo surgimento e por todos os passos das Justiceiras de Capivari, Ildacilde do Prado Lameu, o único rosto conhecido e a voz não anônima desse grupo desfeito em março de 2005, quando sua líder desapareceu por meio de um assassinato brutal.

O relato a seguir visa, portanto, dar voz a um grupo incomum, absolutamente informal, invisível, e corresponde a uma tentativa de verificação da ordem existente nas sombras, partindo do princípio de que apesar da sobrevivência caótica, grupos subalternos socialmente também desenvolvem estratégias próprias de luta para o alcance do que a opinião geral chama de cidadania, e que os habitantes das periferias sociais preferem entender como sobrevivência.

Se a história do grupo se confunde com a história da personagem principal desse artigo, creio que isso não se deve a uma intenção consciente da líder popular de monopolizar todas as decisões, mas às próprias condições em que o grupo surgiu e que estarão expostas a seguir.

Capivari é o nome de um bairro pobre pertencente ao quarto distrito de Duque de Caxias, Baixada Fluminense, Região Metropolitana do Rio de Janeiro. Os seus quase dez quilômetros quadrados o transformam em bastante diverso da grande maioria dos bairros populares caxienses. É provável que o grande tamanho desse lugar tenha sido o primeiro responsável pela sua divisão em áreas distintas que auxiliam os moradores a se localizarem na extensa e escassamente povoada área. ${ }^{1}$

Os raros visitantes do Capivari entram no bairro a partir de uma estrada localizada próxima ao entroncamento de duas importantes rodovias que ligam a cidade do Rio de Janeiro aos principais municípios da região serrana do estado (rodovia Washington Luiz e rodovia Rio -Teresópolis). De início ninguém percebe grandes diferenças entre a entrada do

1 Em média existem entre 300 e 500 habitantes por quilômetro quadrado em Capivari. Isto faz com que a população do bairro varie entre 3000 e 5000 habitantes. Estes números, muito imprecisos, foram obtidos junto à Prefeitura Municipal de Duque de Caxias. 
bairro e as margens das rodovias: logo na entrada existem várias casas semelhantes a qualquer casa de trabalhadores pobres da Baixada Fluminense e fábricas que margeiam avenidas e ruas pavimentadas e com um tráfego mediano de automóveis, ônibus e caminhões.

Tal dinâmica urbana mingua abruptamente a alguns metros de distância das rodovias. Cerca de um quilômetro após o acesso principal do bairro, o casario contínuo desaparece, restando então poucas fábricas, algumas residências transformadas parcialmente em pontos de venda de bebidas alcoólicas, casas humildes e dispersas, ruas de terra batida esburacadas e em alguns lugares ocupadas pelo mesmo tipo de vegetação que enche os inúmeros lotes baldios, que sem dúvida constituem a parte mais freqüente da paisagem deste bairro visualmente perturbador.

Ao longo da estrada principal que corta Capivari a monotonia se mantém. Muita vegetação inútil comprova que a maior parte do bairro não é demograficamente bem ocupada e que os lotes vazios preenchem quase a totalidade dos quarteirões, inundados constantemente por água empoçada pelas chuvas ou pelos diversos cursos d'água assoreados em alguns pontos. ${ }^{2}$ Manchas de povoamento, em geral, existem em poucas áreas mais altas, entretanto persiste a pequena quantidade de gente que se espreme em faixas curtas do bairro que recebem nomes diferenciados. Figueira, Vila Mirim, Morro Grande, Ponte Preta, etc., compõem o que alguns moradores chamam de "núcleo Capivari”, termo usado pelos moradores mais antigos, para os quais não é tudo ali igual, sendo possível pensar em sub-bairros que juntos constituem a grande região do Capivari:

Isto aqui é muito grande... grande demais e o pessoal de fora que conhece aqui... O que pouco que conhece aqui, pensa que é tudo a mesma coisa, só que não é não... não é a mesma coisa não. Aqui é muito grande e essa parte... esta parte daqui mais perto aqui da igreja é mais velha e mais igual roça. Agora fora daqui tem muita terra até Xerém [bairro de Duque de Caxias pertencente ao $4^{\circ}$ distrito e vizinho do município de Petrópolis] e até a estrada pra

2 O bairro de Capivari localiza-se em alguns pontos abaixo em outros ou ao mesmo nível do mar. Diversos rios e riachos cortam o lugar o que faz com que principalmente em época de chuvas o local seja invadido pelas águas que transbordam destes cursos d'água antes de atingirem os maiores rios da região ou a Baía de Guanabara. 
Petrópolis [Rodovia Washington Luiz ou estrada Rio - Petrópolis] e cada um desses lugar tem um jeito seu mesmo e não tem nada com a gente. Tem muito mato e sítio e favelinha cheia de casa, barracão de gente muito pobre que veio pra cá há pouco tempo. (Entrevista com Amadeu da Silva Carlos Filho)

De verdade não é um bairro, é um núcleo de bairros com tudo muito diferente. Tem lugar com algum comércio e ônibus passando, tem lugar mais retirado e sem nada ainda. Não pode chamar de bairro um lugar desse tamanho e todo diferente. Tem favela até e mato em muito lugar. Tem água, natureza. Tem bicho ainda e muita fábrica aqui. De verdade é um monte de bairro e muito lugar que não dá pra chamar de bairro ainda porque não tem nada ainda e é rural ainda. (Entrevista com Álvaro de Souza Peçanha)

Mas o fato é que o grande arquipélago popular que é Capivari não é socialmente tão diverso como os moradores das áreas menos recentes deste "núcleo" conformam-se pensando. Certamente estes sub-bairros não foram ocupados ao mesmo tempo, sendo os mais antigos detentores de mais habitantes e de indivíduos geralmente menos instáveis socialmente. Ao contrário disto, algumas regiões muito recentemente ocupadas possuem pessoas economicamente mais instáveis, desempregados, subempregados ou dependentes de uma agricultura precária praticada em lotes abandonados.

Algo une, entretanto, os moradores destas duas zonas distintas: todos se originam do exterior do bairro, sendo muito comum tanto a presença de migrantes nordestinos, mineiros e capixabas, e filhos destes migrantes, originários já de municípios da Região Metropolitana do Rio de Janeiro, cujos pais nunca habitaram o Capivari, mas que se destinaram àquele "núcleo" devido à sua pauperização e à conseqüente necessidade de manterem-se distantes de aluguéis, dispendiosos para estes indivíduos mesmo em outras áreas periféricas da própria Baixada Fluminense.

Compõe-se, portanto, a população de Capivari de mulheres e homens mais pobres que a média da população de bairros mais populosos e menos periféricos de Duque de Caxias, fato que surge como a conseqüência de ser o bairro um exemplo do fracasso de iniciativas loteadoras na região da Baixada Fluminense. 
Em Capivari o destino dos loteamentos foi diverso daquele trilhado em tantas áreas da Baixada em que eles evoluíram demograficamente até se tocarem e constituírem bairros proletários. Aqui, o grosso dos moradores chegou não antes da década de 1960, uma vez que até essa época as terras que compõem hoje o Capivari, embora não fossem usadas por agricultores, eram ocupadas por donos de gado que na sua maioria não residiam ali, mas que soltavam animais nas regiões menos alagadiças sem muitas preocupações com a delimitação das áreas que seriam ocupadas pelos mesmos. O passado de tradições agrícolas, tão glorificado por memorialistas em outras regiões da Baixada, não existiu em Capivari, e seus moradores mais antigos somente conseguem lembrar-se desse lugar como aquele em que árvores e arbustos foram derrubados para serem transformados em carvão, na época da construção das rodovias vizinhas ao bairro, e onde caçadores circulavam procurando principalmente capivaras, que viviam próximas das vastas áreas inundadas.

Os primeiros loteamentos chegaram unicamente em finais da década de 1960 e não impactaram a rotina desse lugar imediatamente, pois embora muitos tenham sido os indivíduos atraídos pelo valor ínfimo dos lotes e que atenderam à propaganda feita pelas empresas loteadoras, poucos resolveram construir, um número menor ainda decidiu mudar-se para o Capivari e uma quantidade insignificante de pessoas permaneceu morando por lá e bancou enfrentar as dificuldades infindas dali.

A começar pela possibilidade de inundação das casas construídas, passando pela inexistência de serviços elementares - sendo a mais evidente das carências a falta de energia elétrica - e culminando com a ausência completa de meios fáceis de vencer os doze quilômetros existentes entre Capivari e o centro do município de Duque de Caxias, fato que dificultava em muito a chegada dos primeiros habitantes ao Rio de Janeiro, onde trabalhavam, pois para deslocarem-se de qualquer ponto do Capivari até a estação, em que embarcavam em trens que os levavam ao centro do município do Rio de Janeiro, necessitavam vencer a pé distâncias superiores a três quilômetros, até os locais onde ônibus circulavam sem o risco de atolar nos lamaçais.

Em épocas de chuvas, chegar aos pontos de ônibus transformavase em uma missão impossível, tal a densidade dos alagamentos e dos lodaçais em que se transformavam as ruas. Sob tais condições, a desistência do bairro superou constantemente a vantagem inicial que continuou sendo 
ao longo das décadas de 1970, 1980 e 1990 o pequeníssimo valor do lote urbano. O resultado de tudo isto foi o abandono dos loteamentos por seus potenciais ocupantes e a permanência das diversas quadras repletas de terrenos vazios.

A transferência para o bairro de algumas pequenas fábricas ao longo das últimas duas décadas e o surgimento de poucos conjuntos de casas populares garantiu uma tímida intensificação da ocupação humana, não comparável com o crescimento demográfico constante do município de Duque de Caxias. Enfim, as principais características presentes nos loteamentos baixadenses recém constituídos foram acentuadas pelas condições geográficas e mantidas permanentes em Capivari.

$\mathrm{Na}$ inexistência de um passado rural, a memória dos moradores mais antigos do lugar destoa bastante da forma como se visualiza o passado da região em bairros populares da Baixada. No Capivari, as lembranças mais antigas não ultrapassam a década de 1970 e dizem respeito ao passado de dificuldades e às comparações entre esse local suburbano e a "roça", mas também aos episódios repetidos de encontro de cadáveres em meio aos lamaçais e a vegetação de altura média que surgiu após a derrubada das árvores e arbustos que se encontravam ali antes da abertura dos loteamentos:

Quando a gente chegou era muito difícil viver, mas era mais roça e tinha uma vantagem que era poder ficar com tudo aberto porque não tinha violência igual hoje em dia. Depois foi chegando gente e tudo... e ficou mais difícil viver e criar filho. Tá certo que melhorou por causa de condução que tem hoje lá pra baixo. Também é melhor por causa de coisa como hospital e asfalto que já não... que já é até perto daqui agora mas não é mais tranqüilo igual antes porque a gente nunca sabe o que pode acontecer na rua e em casa mesmo. Ainda é melhor que no Rio, mas não é mais roça mesmo e dá medo a covardia. Tá certo que aqui sempre foi lugar de muito corpo jogado na rua... desova... mas era pior quando a gente chegou. Tinha muito corpo mesmo nesse mato e virava mexia a gente achava osso. [...] Era 70 e pouco quando eu vim morar aqui mais ou menos e tinha muita desova. Bandido tinha também, mas não era trafico não. Mas ladrão de galinha era muito mesmo. (Entrevista com Severino da Silva Medeiros) 
Eu vim pra cá em... 1974. Tỉnha nada aqui não, era mato puro mesmo. Pouca casa, pior do que é hoje em dia. Eu sei que é difícil acreditar que era pior que isso, mas era pior porque não entrava ônibus. Não tinha escola nenhuma. Não morava ninguém nessa rua, não tinha luz e aparecia muito corpo aqui. Às vez morria aqui mesmo porque ouvia tiro, mas às vez... mais era que morria fora e jogava aqui. Também não entrava polícia que tinha medo de ficar agarrado na lama e não adiantava chamar não porque eles não vinham e apodrecia aqui mesmo. Urubu e cachorro comia até virá caveira. A gente ia ver primeiro e depois deixava pra lá por causa da catinga. Acabava sem ninguém vim buscar. Eu acho que morria muito mais e ficava sem ninguém ver aí pra dentro nos brejo. A gente só sabia desses que ficava mais pra fora. Lá pra dentro não tinha ninguém mesmo e devia ser mais fácil jogar defunto lá. (Entrevista com Hélio Pereira Bastos)

Muito freqüentemente escapam dos depoimentos dos moradores de Capivari sobre os seus locais de moradia, considerações expressas através de adjetivos como abandonado, esquecido, largado, etc. Tais qualificações, muito presentes também em bairros melhor estruturados da Baixada Fluminense, revestem-se nesse local de uma concordância com a realidade visível bastante acima daquela encontrada em qualquer outro bairro dali.

Em Capivari ações do poder público a rigor nunca chegaram. Através do loteamento revelam a sua existência pedaços de épocas diversas da história de ocupação popular da Baixada . Ali é possível enxergar como a terra foi repartida pelos agentes loteadores, testemunhar hoje dificuldades semelhantes àquelas que os primeiros migrantes que chegaram à Baixada experimentaram, visualizar a resolução informal e solitária dos inúmeros problemas tornados naturais em regiões destinados a migrantes nas periferias da Região Metropolitana do Rio de Janeiro, assistir ao mesmo tempo a ação de bandidos cruéis que agem isoladamente e que praticam principalmente crimes sexuais e assassinatos de mulheres e crianças e a ação de traficantes ligados a grupos criminosos organizados e liderados por bandidos detidos em prisões de segurança máxima, porém responsáveis pela liderança de bandos que utilizam o vasto bairro como refúgio ou como local para a obtenção de mais clientes.

Enfim, esse lugar notabiliza-se por ser um exemplo extremo de iniciativa loteadora fracassada e foi exatamente esse fracasso empresarial que 
o prendeu à sua situação atual e o manteve espacialmente próximo do centro municipal - doze quilômetros - e mesmo do centro do Rio de Janeiro - trinta quilômetros - porém muito distante das condições mínimas de sobrevivência em uma área urbana: o transporte de ônibus até o centro dos dois municípios é recente, precário e circula somente nas áreas em que há alguma pavimentação.

As ruas, quase todas, não são pavimentadas, inexiste saneamento básico em qualquer parte do bairro, e a água utilizada pelos moradores vem geralmente de poços ou nascentes - chamadas de "minas" - existentes no bairro. As ruas, mantidas livres de vegetação unicamente pela ação de seus moradores, não possuem iluminação pública, a não ser que ali se localizem fábricas ou conjuntos habitacionais em construção. Inexistem postos de saúde e os colégios e lojas comerciais localizam-se quase sempre nas áreas do bairro que estão nas vizinhanças da rodovia Washington Luiz. Esta realidade espacial obriga adultos e crianças a se deslocarem a pé, de bicicleta, em lombos de animais ou em carroças até a parte mais estruturada do bairro, que se distancia pelo menos três quilômetros das áreas mais recuadas do Capivari.

A lógica que orienta a ocupação rápida de um loteamento baixadense não funcionou bem ali e mesmo com o surgimento dos primeiros lotes urbanos a área se manteve predominantemente semi-urbana. Ocorre que um loteamento baixadense até hoje somente é ocupado e ganha o status de bairro ou de parte de um núcleo de bairros quando existem em suas vizinhanças motivos para que famílias migrantes ocupem imediatamente os lotes componentes do empreendimento imobiliário. A vizinhança de uma estação de trens, a construção de uma nova rodovia, o surgimento de uma fábrica são fatores detonantes ou incentivadores de crescimento e dinamização destes bairros. Largado à sua própria sorte, entretanto, um loteamento muito raramente sobrevive, sendo o reflexo mais claro deste fracasso exatamente a não construção de um significativo número de casas em seus lotes.

No cenário caótico retratado acima encontramos a personagem principal desse relato, a líder comunitária, dona de casa e agricultora Ildacilde do Prado Lameu, ou Dona Ilda, como era mais conhecida por seus vizinhos de bairro. Nascida em 1947 em Minas Gerais, e assassinada no portão de sua casa em 9 de março de 2005, ela foi moradora do Rio de Janeiro en- 
tre 1959, quando saiu do distrito de Divino Carangola, e 1968, quando conheceu o Capivari, onde seus pais adotivos, que residiam no bairro de Copacabana, compraram uma chácara. A transferência definitiva de Ilda para a chácara da família adotiva, entretanto, não ocorreu naquela época, mas após a morte dos seus pais adotivos, o que aconteceu nos anos finais da década de 1970.

São obscuras, nos depoimentos de Dona Ilda, as razões para a sua migração, que certamente não ocorreu por motivos semelhantes àqueles geralmente alegados pela maior parte dos moradores pobres da Baixada Fluminense. Afirmava ela que sua infância foi miserável e que Divino Carangola a assustava muito devido à violência imperante naquele distrito, tendo sido um de seus tios (que era deputado estadual) assassinado dentro de um de seus estabelecimentos comerciais, localizados no centro do distrito.

A ausência de referências aos pais naturais em suas lembranças acerca da infância chamou a atenção, assim como se mostrou curioso o seu precoce desejo de vir para o Rio de Janeiro para trabalhar como atriz. Os sonhos da menina de doze anos não se concretizaram totalmente, muito embora o seu único trabalho realizado fora do bairro de Capivari tenha sido o de figurante da TV Globo, o que Dona Ilda relembrava muito rapidamente, parecendo misturar orgulho e decepção. Talvez o nascimento de um filho aos dezoito anos tenha selado o seu destino e a conduzido para um casamento tradicional, para uma rotina de dona de casa e finalmente para o Capivari.

Sua atuação comunitária neste bairro, entretanto, não se iniciou unicamente com a sua transferência definitiva para ali, estando os fatos que foram transformados em lembranças importantes para Ilda, quando o assunto era a sua atuação comunitária, localizados no final da década de 1960 e inícios dos anos 1970. Naquela época suas ações restringiramse às tentativas de melhorar o bairro e a vida das pessoas que chegavam ali. Problemas de segurança pública em Capivari eram poucos, uma vez que se relacionavam quase sempre ao aparecimento de cadáveres nas ruas e matagais do lugar recém ocupado por alguns poucos moradores e que servia como local de "desova" para os grupos de extermínio que atuavam mais frequentemente no município do Rio de Janeiro e que esperavam, jogando ali os corpos, camuflarem-nos - uma vez que após se decomporem, acabavam se confundindo com as carcaças de animais que eram também abandonados lá principalmente por proprietários de abatedouros 
clandestinos. Cadáveres estranhos ao bairro não incomodavam se não estivessem nas proximidades de alguma casa habitada e exatamente por isso as ações iniciais de Ilda não se relacionaram com a resolução de nenhum conflito originário das atividades criminosas existentes no bairro.

Apesar de Dona Ilda reforçar em seus depoimentos o fato de que seu bairro era bastante diferente na época em que ela para lá se mudou, ${ }^{3} \mathrm{o}$ feito que escolheu para marcar o início de suas proezas a favor dos vizinhos foi exatamente algo relacionado com a presença de cadáveres próximos de casas já habitadas em Capivari. Muito provavelmente as lembranças idílicas de Ilda sobre "a roça" foram rapidamente embotadas pela luta cotidiana contra a violência que marcou o local nas décadas finais de sua vida:

[...] então daí pra cá... que a gente começou vim pra cá... prestar atenção, eu comecei agir na área... as pessoas matava a pessoa, apodrecia no meio do mato. Cachorro comia, urubu comia, ninguém tirava. Até que uma vez morreu um cara ali já tinha quinze dias que o cara tava morto, o povo pedindo pra tirar na beira do quintal de uma mulher cheia de filho e ninguém tirava. Chamava a polícia, não vinha, fui na prefeitura ninguém tomou as providências. Eu aluguei uma carroça, enrolei o cara podre dentro do lençol, joguei na porta da prefeitura e avisei: "todos que morrerem lá dentro e vocês não ir lá tirar eu pego e jogo na porta da prefeitura”. Ficaram todo mundo em pânico [...] daí pra cá toda vez que eu chamo a polícia a polícia vem tirar, demora, mas tira, não fica mais [...] mas aonde você anda... fosse caminhar aqui você dava de cara com ossada de gente morta e acabou tudo, não tem mais.

As lembranças de Dona Ilda remontam ao início dos anos 1970 e o aparecimento constante de cadáveres de homens desconhecidos em Capivari, relatado pela líder comunitária, parece relacionar-se com a atuação de esquadrões da morte ligados às ações exterminadoras das polícias cariocas que auxiliavam a repressão política levada adiante pelo governos

3 Aliás, em seus depoimentos dizia ser motivo para a sua mudança de Copacabana para a Baixada Fluminense o seu desejo de estar próxima da natureza: “[...] este lugar não tem nada como você está vendo, mas tem estes arvoredos [...]". LAMEU, Ildacilde do Prado. Entrevistas concedidas em 10 jan. 2004; 18 jan. 2005 e 21 jan. 2005 (Todas as falas seguintes de Ildacilde do Prado Lameu originaram-se destes documentos). 
militar existente no Brasil daquele momento. A repetição no depoimento de Dona Ilda de que reclamava com os policiais e que isso não adiantava, parece reforçar a hipótese de que os cadáveres resultavam de justiçamentos promovidos por policiais ou por grupos ligados aos policiais. ${ }^{4}$

Ocorreu que o bairro evoluiu demograficamente, apesar de seu ritmo de crescimento diferir em muito daqueles experimentados pelos demais bairros da Baixada, e enquanto isso ocorria, os problemas dos moradores também se tornavam complexos, diversificando-se também a forma de Dona Ilda atuar. O que não se modificava, entretanto, era a presença estatal. Durante as décadas de 1980 e 1990 as atividades comunitárias da líder popular continuaram a traduzir sua inquietude frente aos problemas de Capivari, mas, no entanto, assemelhavam-se sob vários aspectos às formas dos demais líderes comunitários agirem na região da Baixada Fluminense, sendo possível encontrá-la nestas décadas incentivando seus vizinhos, através de um discurso desafiador e do seu próprio exemplo, a melhorar as condições críticas do bairro, o que equivalia a capinar as ruas, abrir valas de esgoto, comprar entulho que era utilizado para diminuir os buracos das ruas e permitir a entrada de veículos "pelo menos para retirar os doentes".

Para alguns de seus vizinhos o fato de Dona Ilda ter residido em um apartamento no bairro carioca de Copacabana antes de ter se mudado para Capivari transformou a líder em alguém que, diversamente dos demais migrantes, acreditava que seus direitos de morar em um lugar "decente" eram exatamente iguais aos dos moradores da Zona Sul do Rio de Janeiro, e para ela a culpa pelo abandono de Capivari era "em primeiro lugar dos governos e dos políticos e depois do pessoal que comprou aqui e que nunca construiu e que fez isso ficar assim sem nada, porque os governos não se importam mesmo, mas com pouca gente assim, aí que não faz nada mesmo".

Sua história de vida anterior pode até tê-la dotado de idéias diversas daquelas geralmente tidas por quem mora no lugar, apesar disso não há como deixar de considerá-la semelhante aos seus vizinhos, e esta confor-

4 A partir dos primeiros anos da década de 1970 começaram a atuar na região da Baixada Fluminense diversos grupos de extermínio. Alguns dentre eles abandonavam as suas vítimas em áreas mais urbanizadas e passaram a admitir denominações originais ("Mão-Branca", por exemplo). Os matadores destes grupos deixavam sobre os corpos mensagens justificando os assassinatos e os ligando à prática de furtos, estupros, assassinatos, etc., por parte dos justiçados. 
midade surgia em aspectos diversos da vida de Ilda, destacando-se entre esses sua defesa incondicional de princípios morais relacionados com o que chamava de "valores da família", a sua necessidade de manter os filhos próximos de si, sua formação educacional incompleta e a consideração de que o bairro deveria ser cuidado por ela e pelos vizinhos como uma forma de garantir-se pelo menos um pouco de "dignidade" na vida. Entretanto, a figura de Ilda não chamava atenção exatamente pelas suas virtudes ordinárias, ou seja, aquelas características que a ligavam ao seu grupo social e aos seus vizinhos, mas sim pelos seus singulares atributos apontados, aliás, pelos próprios vizinhos.

Ousadia, desapego aos bens materiais, falta de ambição política, consciência, bondade, generosidade, rigor, sensibilidade, agressividade, dentre outras, são características da personalidade de Ilda que, segundo os que a conheciam transformavam-na "na pessoa mais importante do Capivari", "na mãe de todo mundo aquil" ou, menos apaixonadamente, "em uma mulher que luta e resolve tudo quanto é tipo de assunto porque não tem medo de nada".

De fato, a marca distintiva de Dona Ilda em sua última década de vida foi efetivamente a ousadia, tendo sua casa se transformado em um ponto de referência dentro da enorme área carente. Muito embora ela continuasse a ser uma espécie de benfeitora geral do lugar - fato denotado por suas ações assistencialistas, como a distribuição de sopa para desempregados no quintal de sua casa, onde existiam bancos e mesas feitas de concreto para acomodar tanto os moradores carentes que lá iam se alimentar, quanto crianças que não conseguiam vagas em colégios ou que apresentavam baixo rendimento escolar e que assistiam aulas de reforço; além disso, inúmeros e variados casos de violência eram levados até ao seu conhecimento a qualquer hora do dia ou da noite, esforçando-se ela para resolvê-los informal e rapidamente através de suas ameaças e conselhos, muito embora admitisse como regra "registrar os casos mais graves na polícia e exigir ação por parte dos policiais" - suas ações assistencialistas passaram a segundo plano na medida em que mais habitantes chegavam ao Capivari inflacionando o elenco de antigas demandas mantidas sem resolução, ao mesmo tempo em que novos problemas surgiam, exigindo que a líder comunitária elaborasse planos mais sofisticados para que as condições de vida ali não piorassem mais ainda.

Dona Ilda considerava que grande parte dos problemas inerentes aos bairros semelhantes ao seu deviam-se à pequena quantidade de gente 
que os habitava. Sabendo ela que grande parte dos proprietários originais dos lotes existentes jamais retornaria a eles, passou a defender a idéia de que estes lotes fossem invadidos imediatamente por famílias dispostas a construir e cultivar as áreas ainda não ocupadas, a fim de poderem elas mesmas se sustentarem, uma vez que o número de desempregados em Capivari era grande demais. Este plano de Ilda surtiu seus efeitos de forma imediata e a partir dos últimos anos da década de 1990 o número de novos lotes ocupados em Capivari aumentou a olhos vistos. ${ }^{5}$

Na narrativa de Dona Ilda, esta idéia de ocupação dos vários espaços vazios de Capivari surgiu exatamente no mesmo momento em que pela primeira vez ela falou nas Justiceiras do Capivari:

Aconteceu aqui o seguinte: sempre foi violento mesmo... Antes tinha um bandido aqui chamado Jorge Barbudo que matava as pessoa e jogava num buraco. Só que de um tempo pra cá as coisa se alterou muito e além de morte assim de gente desconhecida de fora, desova e essas coisa, passou a ter assalto na rua em casa e coisa pior, tipo morte de pessoa inocente e pior ainda morte de criança, mulher e estupro de criança e mulher aqui... Foi piorando e quando começou a ser assim eu não fiz nada logo, mas me dava uma aflição cada vez maior e minha vontade era matar tudo quanto era bandido que esperava de tocaia menina e menino nos mato para agarrar. Aí eu comecei a limpar estes terreno e roçar estas ruas e pensar que se não fosse tudo jogado e sem ninguém não ia ter tanta covardia. Mas na época eu não botava ninguém na terra ainda. Eu passei mesmo foi a limpar as ruas e mato e a juntar mulher e fazer reunião e só depois é que veio esse negócio de justiceira e de líder que ajeita terra e dá para quem vem chegando agora.

O ponto inicial das ações mais notórias de Dona Ilda é exatamente o momento em que ela criou o grupo Justiceiras do Capivari, e tomou

5 Durante as vezes em que entrevistei Dona Ilda, no quintal de sua casa, várias foram às vezes em que homens e mulheres de aparência muito humilde interromperam nossas conversas em busca de algum tipo de auxílio. Destacavam-se destes pedidos aqueles relacionados à busca por um "pedacinho de terra" como dizia a entrevistada sempre que retornava para a mesa onde narrava a sua vida e as suas ações comunitárias. Andando pelo bairro juntamente com a líder comunitária conheci diversos destes "assentamentos" proletários, formados a partir da eliminação dos matagais, que era o serviço ao qual Dona Ilda mais se dedicava nos últimos anos. 
para si a incumbência de agir de forma muito enérgica contra as ações dos bandidos que atentavam contra a vida de crianças e mulheres dentro do Capivari.

O ano chave para Ilda e suas justiceiras foi 1998, quando ela foi procurada pelos pais de uma menina, Priscila Silva, de oito anos, que havia desaparecido a caminho da escola, e que apesar dos diversos apelos da família à polícia, continuava desaparecida sem que qualquer autoridade pública investigasse. Ilda entrou no caso imediatamente e sem esperar por melhor resultado:

Fui procurar sozinha no mato... nos brejo... no caminho que ela passava pra vim aqui pra estudar... aí acabei achando ela morta no mato, já decompondo a menininha pequena, magrinha. Peguei a menina lá no meio do matagal e trouxe para a rua e aí chamei a polícia pra levar o corpo e chamei a imprensa toda e então decidi não parar mais e juntei as mulheres de perto e fizemos as Justiceiras.

A menina Priscila Silva foi morta após ser sexualmente violentada e esta morte parece ter modificado radicalmente a forma de Dona Ilda pensar o seu papel de líder comunitária:

Desde a morte dela eu vi que não dava pra ficar só ajudando os mais pobre ou incomodando polícia e prefeito e vereador, achando que reclamar só adianta. Continuei ajudando... fazendo tudo junto com os moradores, mas achei que era mais... certo colocar mão na massa e não deixar mas acontecer isto aqui. Reuni as mulheres... era eu e umas cinco no início e a gente ia capinar rua, roçar os matagais daqui... mais esses perto de caminho pra colégio, porque tarado é covarde e faz tocaia no mato. Sem mato eu achava que era mais difícil eles agir.

No ano seguinte, 1999, o assassinato de Milene Souza, de doze anos, violentada e morta também ao ir para o colégio, permitiu outra mutação do estilo de liderança de Ilda e a configuração final do grupo das "mulheres justiceiras":

Com a Milene a coisa mudou porque eu consegui aumentar muito o grupo. De cinco viramos vinte e eu vi que não dava para ficar 
só conversando mesmo. O negócio era partir para a briga mesmo e aí a gente acabou achando o tarado, indo atrás dele e prendendo ele dentro de uma favela lá em Lote XV [bairro caxiense localizado nos limites de Duque de Caxias com Belford Roxo]. A gente ia matar ele, mas a polícia chegou a tempo de não deixar e aí a gente acompanhou ele até a cadeia e ficou lá porque o delegado falou que ia soltar ele porque não tinha prova. Aí eu disse "se soltar a gente mata esse desgraçado na porta da delegacia mesmo" Ele falou que ia prender a gente, eu falei que era direito nosso ficar lá esperando e se o tarado fosse solto a gente linchava ele ali mesmo ou trazia ele aqui pra dentro e matava o cara de tanta porrada.

Daquele momento pra cá nós passamos a andar assim de faca, facão, foice, espada, enxada, pedaço de pau, limpando o mato todo, queimando o mato, abrindo estes caminho e vigiando gente diferente que anda aqui. Se acontece alguma coisa a gente logo aparece. Uma liga pra outra, reúne, junta tudo, foice, machado, enxada e vai atrás, prende, tortura e até mata. Eles pergunta se mata eu falo que mata. Só não falo quem e quanto já matamo. $\mathrm{O}$ trabalho das Justiceiras depois foi esse: levar criança pra escola, limpar o matagal. Agora não que está tudo calmo e a gente não tá vendo nada porque é férias nos colégio. Mas tá voltando e quando volta você pode vim aqui e vai ver duas, três mulher nesses mato limpando mas elas tão mais mesmo é vigiando as criança e vendo se tem estranho na área.

Os casos dos estupros e assassinatos de Priscila Silva e de Milene Souza foram, sem dúvida, marcos fundamentais na vida comunitária de Ilda. Em primeiro lugar estes casos macabros foram responsáveis diretos pelo surgimento e configuração final do grupo de mulheres lideradas por Ilda e, em conseqüência, pela modificação radical na forma como ela comportava-se frente aos seus vizinhos e principalmente na modificação das formas como estes visualizavam-na. Se anteriormente aos assassinatos ela era respeitada e procurada para resolver casos simples de desentendimentos familiares ou para coordenar soluções temporárias para os inúmeros problemas decorrentes das condições urbanas críticas de Capivari, na maior parte das vezes, entre 1998 e 2002, a tônica de suas ações passou a ser o combate à violência que com bastante freqüência passou a 
atingir "as pessoas inocentes" de Capivari. Crianças e mulheres passaram a ser suas principais preocupações e Ilda desde o início percebeu não ser possível para ela sozinha dar conta de proteger todas as mulheres e crianças do bairro:

O problema maior naquela época era como ajudar. Eu sabia que não dava para ficar do jeito que estava até ali e eu só podia contar com uns policiais que eram amigo da gente e vinha quando eu chamava e não dava pra contar com político mesmo porque é... eles não tomam vergonha na cara mesmo e só ajuda se isso rende vantagem pra eles. Apelar pra homem nem pensar. Eles são violento demais pra isso e depois não dava pra contar mesmo com homem de dia porque se está em casa sem procurar nada pra fazer é porque tem alguma coisa errada com eles. De dia e de noite que dá pra contar mesmo era com mulher. Como eu precisava apelei pra elas e um monte veio e a gente reuniu e formou isso.

A recorrência às mulheres parece ter nascido muito mais das razões práticas expostas por Ilda que por alguma causa ideológica, afinal, se era preciso que o próprio "povo de Capivari" cuidasse de sua segurança, se ali dia e noite eram igualmente perigosos e se na visão dessas mulheres, "homens desempregados deveriam estar procurando emprego durante o dia" ou então eram "vadios", restava como única alternativa para a formação das milícias, que deveriam proteger crianças dia e noite, as mulheres vizinhas de Dona Ilda.

A resolução dos problemas relativos à proteção de crianças e mulheres em Capivari, ficou, portanto, entregue ao grupo criado por Dona Ilda e a ação deste grupo de início restringiu-se unicamente ao patrulhamento das ruas do bairro, realizado por grupos de aproximadamente dez mulheres, que sempre circulavam com o rosto encoberto por um lenço e armadas com as ferramentas que elas utilizavam também para derrubar os matagais e desobstruir os diversos cursos d'água existentes em pontos variados do bairro.

Os grupamentos de mulheres revezavam-se a fim de garantir que tanto em horários de entrada como em horários de saída dos colégios diversas mulheres armadas pudessem conduzir crianças através dos capinzais agora batidos e queimados, mas mesmo assim desérticos. À noite a 
escolta também se fazia e as adolescentes que estudavam no horário noturno eram conduzidas por Ilda e por seu grupo, que aproveitava a viagem para dar segurança às mulheres adultas que retornavam dos seus locais de trabalho e que precisavam caminhar dos pontos de ônibus até as suas residências.

Neste ponto é interessante apontar de que forma se estruturaram as ações das Justiceiras do Capivari e como Dona Ilda construiu uma imagem própria para si e para seu grupo. A intenção tanto de Ilda como de suas mulheres era a intimidação dos bandidos e dos potenciais estupradores e homens que espancavam suas mulheres. Investigações de casos de violência contra mulheres e crianças, prisão de bandidos e entrega destes aos policiais eram atos comuns principalmente entre 1998 e 2002. Apesar da pregação da utilização da violência extrema contra "tarados", nunca houve sequer uma ação efetivamente cruel contra os alvos da fúria feminina. A energia que nascia do grupo efetivava-se inicialmente através da substituição integral do poder público dentro do bairro de Capivari e logo em 1998 Dona Ilda percebeu que uma das maneiras de se alterar a situação caótica do bairro era demonstrando a existência daquele lugar para os habitantes de fora do município de Duque de Caxias. O apelo dela à imprensa visava, de fato, demonstrar que Capivari era um bairro-problema e que era preciso que ali "os governos" surgissem como agentes:

De político eu não acho nada muito diferente do que todo mundo acha. Dos governo eu acho que eles precisava ver que a gente existe, [...] que tem o mesmo direito de qualquer outra pessoa no mundo. Acontece aqui que ninguém vê a gente e eu não vou é ficar aqui esperando pra eles ver a gente não, vai dar não, porque eu acho que só dá pra mudar se a gente mesmo faz alguma coisa. Político... governo... pensa só neles e é normal isso mesmo. Rico cuida de rico. Se a gente não aparece ninguém vem levantar aqui quem tá embaixo do tapete igual lixo e ajudar ninguém não. [...] A gente foi pro jornal e rádio pra isso pra mostrar quem a gente é e que a gente existe. Tem direito igual qualquer outro de Caxias ou do Rio de Janeiro mesmo.

Quanto ao modo ostensivo como as mulheres apresentavam as suas armas sui generis, Dona Ilda era enfática em afirmar que aquilo tudo era 
uma estratégia de ação e que a intenção real não foi em nenhum momento tirar a vida de ninguém. Dizia ela que:

Se eu apareço normal na imprensa igual você tá me vendo, preta, 1,60 m, quem vai ligar? Agora armada com a foice e o facão e vestida de roupa diferente, dá ibope. [...] de verdade no início eu tava revoltada e queria matar mesmo, mas depois que a gente resolveu tudo eu esfriei o sangue e voltei ter a idéia de andar certo para não perder o nosso direito. De verdade matar... eu não vejo como sujar a mão com sangue de bandido. Deus fez, Deus leva.

A intenção de apresentar seu bairro surtiu seus efeitos e se desde 1998 era previsível que a ação de Ilda e suas mulheres alteraria substancialmente a rotina do bairro. Não era tão fácil supor, entretanto, que a simples circulação dessas mulheres nas áreas mais abandonadas do bairro e a derrubada e queima dos matagais poderia resultar na diminuição expressiva de todos os casos de violência do bairro. ${ }^{6}$

A partir dos resultados positivos, o ânimo das Justiceiras do Capivari parece ter aumentado e as reuniões semanais do grupo passaram a discutir assuntos diversos, porém todos eles relacionados ainda com os problemas imediatos da comunidade:

De início elas discutiam muita coisa sobre o próprio bairro, como que lugar que deveria ser limpo, qual o tipo de problema que existia e que deveria ser resolvido primeiro, como um colégio devia ser arrumado por elas. Também elas procuravam trocar entre elas informações sobre o bairro. Por exemplo, em uma reunião que eu assisti elas discutiram muito sobre um caso de suspeita de abuso sexual de um pai contra uma filha. A mãe suspeitava e levou o caso para uma das mulheres do grupo. Ilda na reunião resolveu chamar a mãe para ir com ela e a menina ao hospital e depois a delegacia para dar a queixa [...] não sei depois o que aconteceu porque não fui na reunião seguinte. (Entrevista com Marta Mateus Alves)

6 O delegado da $60^{\circ}$ localizada em Campos Elíseos revelou que antes de 1998 os casos de violência sexual e assassinatos de crianças e mulheres em Capivari eram pelos menos dois a cada mês e que entre 1998 e 2004 os casos baixaram para zero. RUBEM, Luiz Carlos. Entrevista concedida em 10 jul. 2005. 
Este depoimento demonstra o que identifico como uma nova mutação das idéias de Dona Ilda e também a conseqüente mudança de rumo das ações das Justiceiras. Ele se refere ao ano de 2003, quando a imprensa regional e grande parte dos habitantes já conheciam Ilda e até se admiravam dela continuar a se recusar a participar efetivamente da vida política de Duque de Caxias, através do cargo de vereadora.

Nessa época, o grande chapéu de palha sobre um lenço de cabelo, o facão na cintura e a foice em uma das mãos eram utilizados muito mais frequentemente quando repórteres iam até ela buscar matérias ou atender a seu convite quando desejava denunciar algo. "As coisas aqui passou a andar calma desde que a gente passou a agir e não tem mais tanta necessidade da gente como polícia. Só umas quatro ou cinco está de frente ainda comigo, mas a gente é mais de cem e quando acontece alguma coisa a gente junta rápido mesmo." $\mathrm{Na}$ verdade a presença das justiceiras, além de "impor respeito", significou a aproximação de Ilda com os poderes públicos, destacando-se dentre estes a prefeitura de Duque de Caxias, a delegacia de Polícia Civil de Campos Elíseos e o $15^{\circ}$ batalhão de Polícia Militar.

Casos graves de violência passaram a ser denunciados imediatamente aos policiais e em seus relatos Ilda enumerava policiais que eram chamados diretamente por ela para resolverem casos em Capivari: “[...] agora é diferente mesmo, eu não reclamo mais de polícia não. Eu tenho o número de uns detetives e do comandante do batalhão e quando a gente precisa eu chamo e eles vêm rápido. A gente sobe no carro da polícia e vai buscar seja quem for." Quanto às autoridades municipais, o diálogo entre Ilda e a "prefeitura" dava-se muito mais através da imprensa regional, na qual ela denunciava constantemente os secretários municipais e o prefeito José Camilo Zito que, segundo ela, era:

[...] só uma farsa. A gente aqui acreditou naquele safado e ele nem voltou aqui depois que ganhou. Não fez uma obrinha aqui mesmo. Lá fora [centro de Duque de Caxias ou margens da rodovia, talvez] ele até mudou algumas coisas, mas nos bairro de dentro igual este nada fez. Eu tinha toda hora era que brigar com os secretário dele que vinha implicar com as casas que a gente faz aqui nestes assentamentos. Eu brigava e dizia que ia botar eles na imprensa e aí eles deixava a gente em paz, mas o secretário de 
habitação, o Aroldo de Brito, era implicante demais. Uma vez veio lá na Vila Mirim com polícia pra derrubar as casa de família que eu assentei lá. Eu digo: "você vai se arrepender porque a primeira casa que você derrubar eu dou um tiro nos seus cornos". Botei eles pra correr e a família está lá assentada do mesmo jeito.

Portanto, não era mais o grupo das justiceiras essencial para a manutenção da segurança do bairro, uma vez que instâncias específicas do poder público passaram a ser acessadas pela população através de Dona Ilda. A mutação final deu-se exatamente neste momento em que um plano de ocupação do bairro evoluía através dos assentamentos e em que algumas necessidades mínimas da população já eram atendidas devido às reivindicações e ameaças feitas por Dona Ilda, e foi exatamente a partir desta última mudança que o desejo de Ilda de agir "pela justiça e pela lei" e não estar "fora da lei" pôde concretizar-se.

A partir do ano de 2003 as justiceiras voltaram-se principalmente para a melhoria das condições de vida das mulheres e das suas crianças. O reconhecimento externo de Dona Ilda facilitou a ida ao bairro de Capivari de profissionais diversos que orientavam as mulheres em assuntos como amamentação, prevenção de doenças próprias das mulheres, educação infantil, direitos das mulheres e crianças. Embora em nenhum momento ao longo do relato das ações comunitárias dos seus dois últimos anos de vida (2003 e 2004) tenha utilizado a palavra cidadania, expressava constantemente a sua idéia de que ela e os moradores de Capivari principalmente aqueles mais pobres - possuíam direitos que eles mesmos não sabiam que possuíam, mas que deveriam ser respeitados "pelos governos e por todo o mundo". Fazer valer o direito dos outros moradores de seu bairro passou a ser a cruzada de Dona Ilda, e um bom exemplo de ação voltada exclusivamente para isto foi a confusão que provocou em um dos cartórios eleitorais de Duque de Caxias, quando conduziu um grande número de novos moradores de Capivari para que estes obtivessem seus títulos eleitorais, sem os quais não poderiam trabalhar:

[...] aliás no ano passado [2004] eu fui tirar... mudar título de pessoa que vem do Ceará, que vem de Minas... transferir pra aqui. Só que eu tive que dar umas porradas em uma mulher lá da TRE porque eu cheguei lá com aquela turma de gente pra poder tirar 
voto, né, porque eu acho que o voto também é muito importante, eu não sou contra o voto, eu acho que todo mundo tem que votar com a consciência né? Não trocar o seu voto por qualquer coisa, por uma cesta básica, uma lâmpada, uma camisa, qualquer coisa, voto tem que ser uma coisa sagrada e não vendida. Então nós foi... eu fui levar as pessoa pra poder trocar o título e tirar aquelas pessoa que nunca teve. Quando eu cheguei lá a mulher começou a debochar da minha cara: "Porque a Dona Ilda dá uma cesta básica" [...] As pessoa chegava lá, o que é que eles quer conta de luz e conta de telefone. Como as pessoas moravam aqui, não tem nem conta de luz nem telefone, eu dei a minha conta de luz e telefone pras pessoa tirar. Aí elas começaram: "é porque essas conta de luz, é porque tudo é Dona Ilda, porque Dona Ilda dá cesta básica, porque Dona Ilda faz isso, porque Dona Ilda faz aquilo." Começou a maltratar as pessoa. Entrou uma senhora grávida de oito meses e saiu de lá chorando. Eu perguntei porque ela tava chorando. Ela falou "Poxa Dona Ilda, a mulher faltou pouco bater na minha cara. E eu atrás da porta ouvindo o que ela tava falando. Aí eu cheguei segurei digo: "escuta aqui, você não tem o direito de fazer isto, aliás, quem tinha de fazer isto era vocês e não eu. Você não tem o direito. Você fica atrás dessa mesa no ar refrigerado, ganhando dinheiro do povo e humilhando as pessoa. Quem é você pra fazer isso? Se eu tô dando a minha conta de luz e a minha conta de telefone pra essas pessoa tirar os seus títulos é porque elas não tem e elas precisa de ter pra trabalhar e pra poder votar também. Então você não tem o direito de maltratar as pessoa". Aí ela virou pra mim: "porque eu vou chamar o juiz pra te prender". Eu digo "chama, mas primeiro eu vou te dar umas porrada". Meti a porrada nela mesmo. Eu ia quebrar tudo lá dentro [...] ai chamei a imprensa, meti na imprensa [...] eu não tenho paciência, eu meto a porrada.

Não mudando seus métodos heterodoxos nesta última fase de sua atuação comunitária, Ilda voltou a aparecer muito mais solitária e caracterizada por:

[...] se meter em todas as coisas e encher o saco de todo mundo. Neste último ano ela não pára mais aqui nunca. Faz de tudo, leva 
gente doente pro hospital com esse carro velho [um carro modelo Jeep ano 1966] a qualquer hora do dia ou noite. Chama secretário de estado e prefeitura aqui e dá $\mathrm{R} \$ 40,00$ num caminhão de entulho pra cobrir buraco nessas rua pro carro da polícia passar. Já falei que tinha que se candidatar a vereadora porque aí podia gastar dinheiro da prefeitura pra ajudar os outros e não o dinheiro do aluguel que ela tem em Copacabana e o da minha aposentadoria pra arrumar rua. [...] eu nunca concordei com isso, ela faz isso porque é teimosa. (Entrevista com P.P.L.)

As narrativas de Dona Ilda, dos seus vizinhos e parentes sobre os seus últimos dois anos de vida caracterizam-se principalmente pela percepção de que ela mantinha sua intrepidez, porém possuía alguns objetivos bastante sólidos e todos eles relacionados à defesa do que chamava de "direitos das pessoas inocentes". É claro que é inútil encontrar dentro do conjunto de idéias tão pragmáticas de Dona Ilda e suas mulheres algo requintado e diretamente influenciado pelas conquistas políticas, sociais e jurídicas obtidas pela sociedade brasileira nas últimas décadas através dos diversos estatutos de direitos de terceiro grau, ${ }^{7}$ porém é fato que este conjunto de idéias que orientavam as atitudes de Dona Ilda e de seu grupo diferiam sutilmente também das formas de se pensar na resolução de problemas na Baixada Fluminense através das lideranças comunitárias. É claro que em alguma medida o jeito de se resolverem os problemas práticos em Capivari assemelharam-se ao próprio modo informal da população baixadense lidar com as ausências públicas.

Espalhar entulho nas ruas para permitir a passagem de pedestres e carros é um bom exemplo de resolução informal levada adiante com ou sem a presença, muitas vezes unicamente catalisadora de um líder comunitário, entretanto, para Ilda o ato ordinário de pavimentar precariamente as suas ruas significava em último caso facilitar o acesso seu e de seus vizinhos aos órgãos do poder público.

7 Direitos de terceiro grau constituem a conseqüência do que Norberto Bobbio chama de expansão geral dos direitos, o que é uma característica das sociedades do Ocidente nas décadas posteriores à segunda guerra mundial. Ainda segundo este autor os direitos de terceiro grau são conseqüências do surgimento dos direitos sociais e a garantia da sua aplicação depende da intervenção direta do Estado que precisa transformar-se e passar a ser um Estado Social (Bobbio, 2004. p. 86-87). 
A eliminação de matagais é também algo corriqueiramente praticado por moradores de áreas loteadas recentemente na Baixada. Para Ilda, no entanto, esse trabalho, inicialmente reativo perante os estupros e assassinatos de crianças e mulheres dali, transformou-se em um dos componentes da estratégia da líder de expor seu bairro-problema através da imprensa e mais ainda como uma forma de transformá-lo por meio do assentamento de novos migrantes em terrenos delimitados diretamente por Dona Ilda e suas mulheres e da destinação de algumas destas áreas ao cultivo de frutos, destacando-se dentre estes o maracujá, a banana, a acerola, o coco e algumas verduras e ao implemento de criações de pequenos animais como galinhas, coelhos, cabritos, rãs e minhocas. A preocupação de Dona Ilda era a de não permitir que a diminuição da área ocupada pelos matagais significasse o aumento do número de desempregados em Capivari e a formação de favelas ali.

O retorno ao passado agrícola inexistente no bairro, porém presente na memória de grande parte dos migrantes moradores de Capivari, parecia para a líder uma solução adequada para alguns dos tantos problemas permanentes do Capivari.

Acostumada, por toda a vida, "a falar alto e dar porrada" em autoridades públicas, homens que espancavam suas mulheres e filhos, estupradores e assassinos de criança, Dona Ilda parece não ter adaptado o seu estilo de liderança às mudanças drásticas que seu bairro experimentava com a aceleração demográfica e o surgimento do que ela mesma classificava como um novo tipo de bandido:

De uns anos pra cá tem mudado os bandidos daqui. Sempre teve muito, mas de verdade eu não dava muito por eles não. Quando a gente pegava esses matador de mulher e criança aí e dava um pau eles se cagava todo com medo de morrer mesmo e pedia pelo amor de Deus e tal. Eu não tinha medo mesmo e não tenho agora porque eu não sei o que é medo mesmo, mas eu sei que é diferente porque antes não tinha esse negócio de droga não. Eles até usava, mas buscava longe e nem tinha aqui na Baixada não. Agora... agora é aqui nas nossa cara mesmo e eles usa assim livre. Antigamente não a gente nem nunca via usando. Agora vive em bando também.

A constatação da existência de novos bandidos obrigava Ilda a negociar: 
Eu por exemplo não sou amiga nem inimiga. Eu sou contra aquele bandido que mora na área e suja a área. Eu sou contra aquele bandido que vem pras portas das escola pra viciar as criança. $\mathrm{E}$ sou contra aquele bandido que mexe com a comunidade. A gente não se mistura com bandido. Mas quando a gente vê que a coisa tá demais do lado deles a gente vai a eles. Há pouco tempo eles tava assaltando cabo de telefone aqui. Nós fomos a eles pra saber se era eles que tava fazendo esse tipo de coisa: "não, não somos nós". Eu digo "vocês vão ver quem é que a culpa vai cair em cima de vocês. Nós vamos botar os homem [polícia] em cima". Pararam. Tem uns dois mês que eles pararam com isso. Já morreu também uns seis.

Essa negociação parecia difícil porque Dona Ilda não mudava seus princípios e possuía uma noção de territorialidade que entrava em conflito direto com o desejo dos traficantes de utilizarem-se das "pessoas inocentes" da forma como entendessem, viciando seus filhos e utilizando a parte instável da "comunidade" como funcionários do tráfico. Além de não perceber o perigo contido na disputa, Ilda insistia em entabular negociações ao seu modo e em não reconhecer os "direitos" de traficantes manterem seu comércio e atividades criminosas:

Nós não apoiamos bandido. Eles me respeita. O direito de um termina quando do outro começa. Então é o que eu falo pra eles: "seu direito termina quando o meu começa [...] então você não invade a minha área, não mexe com as pessoa inocente e pronto." E é assim que eu faço. [...] aqui quem comanda também é uma mulher. [...] a gente não dá confiança, a gente não quer se misturar. Nós estamos brigando pelas nossas crianças e pra melhorar o lugar. Inclusive a gente tá brigando sobre tudo isto, acabar com os bandidos. Também. A gente sabe que não vai conseguir, mas o que a gente pode fazer a gente tá fazendo. Porque os bandidos... enquanto eles estão na deles, não mexe com ninguém, mas o pior quando eles começa entrar na nossa área pra viciar nossas criança. A gente não aceita.

Exatamente a não aceitação da venda de drogas nas ruas próximas dos colégios de Capivari rendeu a Dona Ilda as primeiras ameaças de 
morte da sua longa carreira de líder comunitária. A partir da favela VaiQuem-Quer, localizada nas cercanias do bairro, a traficante Merinália de Oliveira, a "Índia", esposa de Carlos Brás Vitor Silva, ou "Fiote" - este um dos comandantes do grupo do traficante Fernandinho Beira-Mar ordenou a sua morte, acusando Dona Ilda de ser delatora. ${ }^{8}$

Em Capivari há também a suspeita de que o fato detonador do assassinato de Ilda foi o seu empenho em encontrar o corpo de Maria de Jesus, de 73 anos, desaparecida no final do mês de fevereiro de 2005 e cujo corpo foi encontrado no dia primeiro de março em um matagal.

Ilda descobriu que um dos "novos bandidos" dali devia dinheiro àquela senhora, que sobrevivia vendendo bebidas em uma "barraca". Quando a senhora cobrou a dívida, foi morta pelo bando e jogada em um dos muitos locais ermos de Capivari. Ilda soube desta história, contou-a aos policiais e a partir daí acendeu a fúria dos traficantes que a assassinaram no dia nove de março de 2005, às 19:30 h, quando alguns desses novos bandidos, "crias do bairro" e que ela acreditava que a respeitavam, chegaram até o portão de sua casa, comunicaram o encontro de um cadáver no início da rua e pediram água à líder comunitária, que ao virar-se para atender o pedido foi atingida por cinco tiros, quase todos em sua cabeça.

Seu enterro ocorreu no dia seguinte e, segundo os mesmos jornais que registraram sua trajetória comunitária, foi bastante concorrido, sendo ela homenageada por autoridades municipais, estaduais e até por um representante do governo federal. O prefeito de Duque de Caxias decretou luto oficial de três dias no município e as investigações policiais visaram desde cedo os traficantes de Capivari e de favelas não muito distantes dali. Finalmente em abril de 2005, a chefe dos traficantes operantes nestes bairros foi presa e o caso Ilda do Prado esquecido pela imprensa e autoridades regionais.

Mas efetivamente essa morte era inevitável? Considerando o número de líderes comunitários assassinados nas ultimas décadas, a resposta a essa pergunta pode ser "sim". O assassinato de líderes comunitários semelhantes à Dona Ilda é rotineiro tanto nos bairros populares da Baixada

8 Após sua morte a casa de Dona Ilda foi pichada com as seguintes mensagens " $\mathrm{CV}$ (Comando Vermelho) e VQQ (Vai-Quem-Quer), depois de morta você revelou sua cara: X-9 [informante da polícia]". 
Fluminense quanto em favelas e conjuntos habitacionais cariocas, onde estes precisaram conformar suas ações aos desejos dos "donos" do tráfico a partir da globalização do comércio de drogas e da privatização de favelas, conjuntos habitacionais e bairros habitados pelas classes subalternas.

O habitual nesses novos tempos é que a liderança comunitária submeta-se aos desejos de traficantes, ocorrendo os assassinatos de líderes comunitários principalmente quando esses cometem erros estratégicos, como se aliarem a inimigos de traficantes momentaneamente fortes, servirem como olhos e ouvidos de policiais, recriminarem publicamente e sem justificativas o comportamento de bandidos, levarem adiante projetos comunitários sem aval do tráfico ou, no extremo, perceberem-se como detentores do controle da "comunidade", ou seja, competirem pela liderança diretamente com os traficantes.

O visível não conformismo de Ilda, o seu apego ao que julgava ser uma tradição local de pouca importância do tráfico de drogas e a sua crença de possuir corpo fechado 9 e por isso localizar-se acima da possibilidade de ataque direto, levaram-na a subestimar a força de seus oponentes e representantes de um novo tempo, em que às desgraças diárias das quais ela defendia a sua "gente inocente" era preciso acrescentar o poder das pesadas armas possuídas pelos bandidos, desejosos de incentivar o consumo das drogas e para os quais não existia nenhuma outra forma de lidar com a população a não ser através da violência mais explícita, inexistindo ali em Capivari e nos bairros vizinhos razões para que traficantes mantivessem uma relação amigável com os moradores.

Certamente é recorrente na literatura clássica acerca de cidadania no Brasil o entendimento de que neste país os direitos sociais em grande medida não foram conquistados pelos cidadãos, porém doados pelas mãos das elites. Recentemente, entretanto, conforme aponta Ângela de Castro Gomes (2004), a produção historiográfica brasileira tem se caracterizado por

9 Não é incomum o encontro de líderes populares baixadenses que se imaginaram possuidores do que chamavam "corpo fechado". Além de Dona Ilda, o vereador e os justiceiros entrevistados por mim para a confecção de um dos capítulos de minha tese de doutoramento ostentavam essa qualidade. A tradição do corpo fechado ali parece ter se iniciado com Tenório Cavalcanti, atingiu o primeiro prefeito de Belford Roxo (Joca) e foi tema de dois filmes ambientados na região da Baixada Fluminense, a saber Amuleto de Ogum produzido em 1974 e dirigido por Nelson Pereira dos Santos e O Homem da Capa Preta, produzido em 1986 e dirigido por Sergio Rezende. 
uma percepção menos estreita das relações políticas que envolvem "dominantes e dominados". A submissão popular em obras de historiadores atuantes nos anos pós-1980 já não é tão absoluta a ponto das mulheres e homens pertencentes às classes populares serem considerados "parceiros fantasmas". Escravos, operários urbanos, trabalhadores do campo, dentre vários outros estratos dos grupos socialmente subalternos desenvolveram identidades relativamente próprias ao longo dos processos políticos, sendo percebidas hoje como simplificadoras as visões desses estratos sociais como eternos conduzidos e consumidores de uma cultura política emanada de cima.

É um fato, entretanto, os esforços estatais na manutenção das massas habitantes tanto das periferias das cidades quanto das áreas rurais do interior, distantes da necessidade de reivindicar direitos através de mobilizações de qualquer tipo. ${ }^{10}$ O que levou José Murilo de Carvalho (2005, p. 110) a considerar as ações estatais favoráveis à extensão dos direitos sociais como algo inspirado no perigo das reclamações populares - potencialmente revolucionárias - tornadas possíveis principalmente pelas grandes migrações campo-cidade que marcaram a história nacional no período imediatamente posterior ao início do processo de industrialização do país, inaugurado com o advento da era Vargas em 1930 e acelerado ao longo da década de 1970, em plena época do "milagre econômico", quando até mais abundantemente os migrantes chegaram às periferias das principais cidades do sudeste brasileiro.

A solidificação dos direitos sociais, "doados" por Vargas ao longo dos seus governos e quase unicamente representados pelas leis trabalhistas e previdenciárias, permitiu aos agentes políticos oficiais lidarem com uma calma popular tornada estrutural e que parece ter possibilitado a criação da tradição brasileira de tutelarem-se/desmobilizarem-se quaisquer ações políticas populares.

A tutela constituiu-se na forma mais branda de desmobilização popular, acima dessa esteve sempre a repressão pura e simplesmente violenta experimentada, por exemplo, pelos líderes favelados cariocas que nos piores momentos do regime de exceção inaugurado em 1964 desapareceram por "sovietizarem" os guetos populares.

10 Surge como exemplo de direito social doado, o início, precário, na década de 1920 do nosso sistema de previdência social. É curioso que a instituição da Caixa de Aposentadoria e Pensões dos Ferroviários tenha se dado a partir da iniciativa dos patrões (cf. Luca, 2003. p. 475). 
Apesar das décadas posteriores à segunda guerra mundial serem consideradas por Norbert Bobbio (2004) como a "era dos direitos", não significou essa percepção de novos direitos sociais como básicos uma automática tomada de consciência da necessidade de extensão desses "direitos do Homem" para o conjunto da sociedade.

Quando o alvo das análises são as classes populares é bem mais difícil verificar como tais novidades jurídicas foram percebidas e ofertadas e o desrespeito aos diversos novos direitos elencados por Bobbio tornouse regra mais evidente em momentos de crise como aqueles em que as periferias urbanas fugiram da invisibilidade pelo aumento físico de seu tamanho, quando camponeses inseridos no mundo capitalista à força passaram a reivindicar propriedades privadas ou a manutenção das suas tradições, quando trabalhadores urbanos não se conformaram com os direitos parciais "doados" e a tutela do Estado ou mesmo quando estudantes ousaram reivindicar a possibilidade de discordar das idéias oficiais.

A carreira comunitária de Dona Ilda espelha de forma exemplar essa convivência com uma cidadania partida, em que mesmo na época atual, quando a liberdade de expressão é total e a manifestação de insatisfações não é algo perigoso - pelo menos quando o interlocutor é o Estado inexistem espaços para a revolta ou para a reivindicação como maneiras de resolução dos problemas mais perceptíveis agora devido à democratização do Brasil em 1985.

Reivindicar foi uma estratégia acessória das ações de Dona Ilda, e visava essa estratégia tão somente "fazer o Capivari existir para quem não mora aqui e que nem sabe que aqui tem gente de carne e osso". Ao longo de toda a sua carreira, importante de fato era para esta mulher sua luta quase solitária para organizar o espaço comunitário, "abandonado pelo governo". Fundamental em suas falas foi sempre a inocentização dos moradores do Capivari, vítimas do esquecimento.

Tal esforço no sentido de proteger mulheres e crianças mostra-se facilmente como a expressão máxima de seu assumido papel maternal, interpretado como assistencialista por qualquer estudioso de fenômenos sociais. Eu considerei que a originalidade de Dona Ilda e de seu grupo de mulheres nasceu exatamente do isolamento ao qual foram os habitantes de Capivari sujeitos. Esdrúxulos atores surgiram nesse mundo esquecido e caótico.

A providência inicial de tais personagens parece ter sido sempre transformar o espaço onde a desordem era a regra. Por isso criar leis próprias 
nunca pareceu uma usurpação na medida em que "a terra de ninguém" era a única de propriedade desses homens, mulheres e crianças que precisavam sobreviver apesar das inundações, dos "tarados", mosquitos, falta de moradia, documentos, emprego, escola, polícia, postos de saúde, ônibus.

Intimidar-se frente aos direitos de alguém que comprou um terreno "há um tempão" e que agora vem reclamar a sua propriedade ou perante a autoridade de um secretário municipal "omisso" que ameaça derrubar casas construídas "com sacrifício", porém de forma irregular, pois sobre terreno alheio, ou respeitar uma funcionária pública que tem a "coragem de maltratar uma grávida" parecerá - mesmo para aqueles que não experimentam na pele os problemas dos que vivem em Capivari - ilógico quando descobrimos que as "leis de Ilda" visavam exatamente inserir seus "inocentes" em um mundo que contivesse uma das palavras preferidas da líder popular strictu sensu: direitos.

A tragédia da morte de Ilda encerrou não somente sua carreira política, mas fez o grupo de mulheres mascaradas lideradas pela líder desaparecer. Algumas escolas foram abandonadas pelas crianças porque os matagais voltaram a crescer e menos de um mês após a morte da líder dois menores foram mortos após serem violentados. O caos parece rondar o local antes patrulhado por Ilda e do qual muitos moradores fugiram temendo a ação vingativa dos traficantes. Os policiais continuam entrando unicamente para acompanhar o recolhimento dos corpos e receber o "arrego" dos traficantes. A prefeitura mantém-se distante do local que continua sendo inundado a cada nova tempestade.

Sem as "leis de Ilda", as ilhas habitadas desse bairro arquipélago repleto de medo, "lama e mato", tornaram-se definitivamente redutos do tráfico e dos mais diversos tipos de bandidos, evidenciando em primeiro lugar a inexistência nesse país de um Estado social de fato e demonstrando a impossibilidade de se prescindir nas áreas habitadas por classes subalternas das ações levadas adiante pelas lideranças políticas populares strictu sensu representadas por Ildacilde do Prado Lameu no presente artigo.

Iniciei esse artigo afirmando que a cidadania é algo pensado no Brasil atual como não alcançado completamente pelo conjunto da sociedade. Chamaram a atenção dos estudiosos com muita freqüência aqueles grupos sociais facilmente visíveis como os trabalhadores, as mulheres, os negros ou os homossexuais. A repetida presença das manifestações desses 
grupos na imprensa nacional pode ser uma explicação para o reconhecimento de suas lutas por inclusão. Instáveis habitantes de nossas periferias urbanas parecem, ao contrário, condenados ao esquecimento, sendo injusta a consideração dessas mulheres e homens como apáticos e conformados com o seu papel socialmente marginal. Ao invés disso, eles lutam para serem reconhecidos como cidadãos de fato.

Figuras como Ildacilde do Prado Lameu representam bem o tipo de liderança possível em uma periferia urbana brasileira e a partir da ação dos componentes das classes subalternas existentes ali. De uma certa forma elas expressam a própria maneira dessas populações pobres defenderemse dos efeitos da pequena ou inexistente presença estatal.

Não exatamente abandonando a reivindicação, porém comprovando a sua ineficácia, líderes políticos populares strictu sensu como Dona Ilda notabilizam-se por organizar as invisíveis ações populares na região da Baixada Fluminense, transformando-se em pontos de referência para seus semelhantes e expressando a cultura política existente ali desde a colonização proletária da região.

\section{Referências bibliográficas:}

BOBBIO, Norberto. A era dos direitos. Rio de Janeiro: Elsevier, 2004.

CARVAlHO, José Murilo de. Cidadania no Brasil: o longo caminho. $7^{\text {a }}$ ed. Rio de Janeiro: Civilização Brasileira, 2005.

GOMES, Ângela de Castro. Questão social e historiográfica no Brasil do pós-1980: notas para um debate. Estudos Históricos, Rio de Janeiro, FGV, n. 34, 2004.

LUCA, Tânia Regina de. Direitos sociais no Brasil. In: PINSKY, Jayme; PINSKY, Carla Bassanezy. História da Cidadania. São Paulo: Contexto, 2003.

\section{Entrevistas}

ALVES, Marta Mateus. Entrevista concedida em 3 de junho de 2004.

BASTOS, Hélio Pereira. Entrevista concedida em 18 de dezembro de 2004.

CARLOS FILHO, Amadeu da Silva. Entrevista concedida em 5 de outubro de 2004.

LAMEU, Ildacilde do prado. Entrevistas concedidas em 10 de janeiro de 2004; 18 janeiro de 2005 e 21 de janeiro de 2005.

MEDEIROS, Severino da Silva. Entrevista concedida em 16 de janeiro de 2005.

P.P.L. Entrevista concedida em 18 de janeiro de 2005. 
PEÇANHA, Álvaro de Souza. Entrevista concedida em 15 de janeiro de 2005.

RUBEM, Luiz Carlos. Entrevista concedida em 10 de julho de 2005.

Resumo: O presente trabalho propõe-se a explicitar as maneiras como surgiu, desenvolveu-se e foi interrompida através do assassinato a liderança comunitária de Ildacilde do Prado Lameu, que atuou ao longo das últimas três décadas no bairro de Capivari, periferia do município de Duque de Caxias, Baixada Fluminense, Região Metropolitana do Rio de Janeiro. Ildacilde, ou simplesmente Dona Ilda, destacou-se dos demais líderes comunitários regionais principalmente por ser mulher, pelos seus métodos exóticos de chamar a atenção para os problemas dos cidadãos-sós de seu bairro, pela criação e liderança de um grupo de mulheres (Justiceiras de Capivari), pela sua recusa a comunicar-se politicamente através dos meios tradicionalmente disponíveis e sobretudo pela sua radical e intransigente defesa dos direitos "das pessoas inocentes".

Palavras-chave: cidadania; liderança comunitária; direitos civis; violência urbana;

The trajectory of Ilda do Prado Lameu: popular dynamism and citizenship in a periphery of Rio de Janeiro

Abstract: The present work aims to explain the ways in which Ildacilde do Prado Lameu's community leadership came out, developed and was cut short by murder, who acted within the last three decades in the neighborhood of Capivari, in the outskirts of Duque de Caxias city, Baixada Fluminense, Metropolitan Region of Rio de Janeiro. Ildacilde, or simply Dona Ilda, stood out against the other community leaders mainly because of being a woman, by her exotic methods on drawing attention to the problems of the alone-dwellers of her neighborhood, by the creation and leadership of a women group (Justiceiras de Capivari), by her refusal in communicating politically through the available traditional means, and, especially, by her radical and non-tolerant defense of the rights of "innocent people".

Keywords: citizenship; leadership community; civil rights; urban violence. 